\title{
SSynthesis
}

International Scientific Conference of IT and Business-Related Research

\section{LOCAL COMMERCE ON SOCIAL NETWORKS IN MEXICO AND ITS REGULATIONS}

\author{
LOKALNA TRGOVINA NA DRŠTVENIM MREŽAMA \\ U MEKSIKU I NJENE ZAKONSKE REGULATIVE
}

\author{
Juan Emmanuel Delva Benavides ${ }^{1}$, Ma Teresa Prieto Quezada ${ }^{2}$, Jean Claude Delva Exume ${ }^{1}$ \\ ${ }^{1}$ Universidad de Guadalajara, Centro Universitario de Ciencias Económico Administrativas, Periférico Norte ${ }^{\circ}$ 799, Núcleo Universitario \\ Los Belenes, C.P. 45100, Zapopan, Jalisco, México \\ ${ }^{2}$ Cuerpo Académico 508, Centro Universitario de Ciencias Económico Administrativas, Periférico Norte N 799, Núcleo Universitario Los \\ Belenes, C.P. 45100, Zapopan, Jalisco, Departamento de Investigación
}

\begin{abstract}
:
The Internet is a double-edged weapon whose effects depend on the intervention of the Government and its regulations. The e-commerce is not an exception and Mexico is making continuous efforts to make the Internet a safe virtual space for the Mexican consumer who spent 9.2 thousand million dollars via the Internet in 2013. The same applies to traditional commerce where trade is regulated by the Law and in order to exist they need their corresponding license. The Local Governments are to regulate this situation, but, as any Government, they are limited by their territorial jurisdiction. Thus, even though citizens are willing to use social networks as ad spaces for local commerce, not even the City Halls of the largest metropolis in Mexico have inspectors or tools capable of supervising local commerce through social networks, which makes the consumers vulnerable to frauds and affects the formal merchants. Due to the efforts of the Mexican government within the Telecommunications reform, the number of the Internet users will increase, along with the number of social network users, thus resulting in altered Internet habits of the Mexican Society and the evolution of local laws.
\end{abstract}

\section{Key words:}

City Hall, consumers, Internet, laws

\section{Apstrakt:}

Internet predstavlja mač sa dve oštrice čiji uticaj zavisi prevashodno od intervencije Vlade i njenih propisa. Elektronska trgovina nije izuzetak tome i Meksiko ulaže kontinuirani napor kako bi Internet postao siguran virtuelni prostor za Meksičke korisnike koji su potrošili 9,2 milijarde dolara preko Interneta u 2013. godini. Isto važi za tradicionalne oblike trgovine koji su regulisani zakonom,a za koje je neophodno pribaviti odgovarajuće dozvole. Lokalne vlasti bi trebalo da regulišu ovu situaciju, ali kao i svaka vlada, imaju ograničenu teritorijalnu nadležnost. Stoga, iako su građani voljni da koriste društvene mreže kao prostor za oglašavanje svoje lokalne trgovine, čak ni gradske većnice najvećih metropola u Meksiku nemaju inspektore i potrebna sredstva za nadgledanje lokalne trgovine putem društvenih mreža, što čini korisnike podložnim prevarama i utiče na trgovce. Uprkos naporima Meksičke vlade u okviru reforme iz oblasti telekomunikacija, broj Internet korisnika će se povećati zajedno sa brojem korisnika na društvenim mežama, što će u velikoj meri uticati na navike Internet korisnika iz Meksika kao i na razvoj lokalnih zakona i regulativa.

Ključne reči:

gradska većnica, potrošači, Internet, zakoni

\section{Acknowledgements:}

The authors would like to thank Iván Said González López and Nadia Marlene Carreon Zamora for their assistance, as well as to the "Centro Universitario de Ciencias Económicas y Administrativas", within the University Of Guadalajara for encouragement and support provided.

\section{INTRODUCTION}

Social networks have become more than just a way to communicate with friends and family. Namely, they also serve as channels that governments can use to send official messages, places where huge companies can expand their new products and as information tools in the Egyptian revolution of 2011 (Valenzuela, 2011). The reaches of these networks are well-known when we study them as examples of tools where boundaries are worthless. But, what if there are situations where the boundaries are necessary for the governments to play their respective roles on exercising their own power? In Mexico, the local governments - city halls - which are responsible for the public security, drinking water, drainage, sewage, markets and supply centers, streets, parks and gardens along with many other issues (Chamber of Deputies, 1917), received their funds mostly from the federal government (Chamber of Deputies, 2015) and from the money gathered from citizen contributions such as taxes or license fees in order to operate properly (Official Gazette of the State of Jalisco, 2015).
Since Mexico is a federal nation, it is divided into States that are further divided into Municipalities with a City Hall being responsible for infrastructure improvements and proper delivery of public services (Chamber of Deputies, 1917). However, City Halls can only operate within a limited geographical region, and thus all their faculties must be restricted to their territorial jurisdiction. As previously mentioned, municipalities can collect revenue when giving licenses or taxing, but if a local commercial practice occurs in virtual space, the local government is unable to exercise its power. Consequently, it will miss the possibility of gaining revenue and will not be able to verify if all of the business requirements have been approved. Municipalities are the cornerstone of the sociopolitical transformations and the fundamental axis of Mexico's development (Vallarta, 2002), which is why it is very important to ensure that their faculties are being improved along with the social evolution, as this may happen since $43.5 \%$ of Mexicans are the Internet users (INEGI, 2014), and $90 \%$ of them have at least one social network (Menéndez \& Enríquez, 2014) and only 5.8\%, or more than 46 million users, purchase goods or do their billings online (INEGI, 2014). 


\section{RESULTS AND DISCUSSION}

\begin{tabular}{|c|c|c|c|c|}
\hline CITY HALL & $\begin{array}{l}\text { LOCAL BUSINESS } \\
\text { REGULATIONS }\end{array}$ & $\begin{array}{l}\text { REGULATIONS } \\
\text { OF PHISICAL ADS }\end{array}$ & $\begin{array}{l}\text { LOCAL BUSINESS } \\
\text { REGULATIONS ON } \\
\text { SOCIAL NETWORKS }\end{array}$ & $\begin{array}{l}\text { REGULATIONS OF } \\
\text { ADS ON SOCIAL } \\
\text { NETWORKS. }\end{array}$ \\
\hline Zapopan & $\begin{array}{l}\text { Regulation of Trade and Services for the mu- } \\
\text { nicipality of Zapopan. }\end{array}$ & $\begin{array}{l}\text { Advertising Regulations for } \\
\text { the Municipality of Zapopan. }\end{array}$ & Does not exist & Does not exist. \\
\hline Guadalajara & $\begin{array}{l}\text { Regulations for the Operation of Commercial } \\
\text { and Industrial lines } \\
\text { and Provision of Services in the Municipality } \\
\text { of Guadalajara. }\end{array}$ & $\begin{array}{l}\text { Regulation Of Advertisements } \\
\text { For The Municipality Of } \\
\text { Guadalajara. }\end{array}$ & Does not exist & Does not exist. \\
\hline Monterrey & $\begin{array}{l}\text { Rules For the Use Of The Public Street In The } \\
\text { Exercise Of Business In Monterrey, Nuevo } \\
\text { Leon. }\end{array}$ & $\begin{array}{l}\text { Advertisements Rules Of The } \\
\text { City Of Monterrey. }\end{array}$ & Does not exist & Does not exist. \\
\hline Mexico City & $\begin{array}{l}\text { Commercial Establishments Law of the Fed- } \\
\text { eral District. } \\
\text { \& } \\
\text { Commercial Establishments Rules of the Fed- } \\
\text { eral District regarding capacity and security } \\
\text { establishments with and area of impact. }\end{array}$ & $\begin{array}{l}\text { Outdoor Advertising Law Of } \\
\text { Federal District. } \\
\& \\
\text { Regulations of the Law Of } \\
\text { Federal District Outdoor } \\
\text { Advertising }\end{array}$ & Does not exist & Does not exist. \\
\hline Querétaro & $\begin{array}{l}\text { Regulations For The Development Of Com- } \\
\text { mercial Activities in the Street in The Munici- } \\
\text { pality Of Querétaro. }\end{array}$ & $\begin{array}{l}\text { Regulation Of Urban Image } \\
\text { For Municipality Of Queré- } \\
\text { taro. }\end{array}$ & Does not exist & Does not exist. \\
\hline
\end{tabular}

Table 1. Cities in Mexico where traditional local commerce and advertising are well- regulated, but the commerce and advertising via social networks is still poorly regulated.

\section{NATIONAL PROTECTION OF MEXICAN CONSUMERS}

On February 5, 1976, the Federal Law of Protection to the Consumer enriched the social rights of the Mexican people, and for the first time established the rights for consumers and specialized agencies in the proxy of justice in the sphere of the consumption. The National Institute for Consumers and the Federal Attorney's Office of Consumer (PROFECO) were established, as an organism decentralized of social service, juridical personality and own patrimony with functions of administrative authority entrusted to promote and protect the consuming public interests. Mexico is the second Latin-American country with the Federal Law of Consumer Protection and the first one to have established the Attorney's office (PROFECO, 2015 a).

The objectives of PROFECO include the following:

- to protect and defend the consumers' rights.

- to promote consumers' rights.

- to foment a culture of intelligent consumption.

- to promote equity in trade relationships.

- to ensure legal certainty in trade relationships.

- to improve institutional performance

There is also the monitoring of virtual stores. For instance, the last one was performed on January 15, 2015, where PROFECO supervised whether these virtual shops had proper privacy policies, personal security and financial data, physical address, landline number, detailed description of goods or services, total costs and taxes, payment method reports, terms of delivery or shipping, conditions in case of cancellation, refunds or exchanges, and if the store is committing any kind of fault law (PROFECO, 2015 b).

Actually, there is an institution in Mexico with the vision to become an amicable institution, effective in consumer protection, known for its strict law enforcement, and the ability to promote citizen participation and education for responsible consumption. However, as helpful as it might be, PROFECO (2015 a) cannot issue permission or licenses for local commerce, but it can impose fines or in case of serious misconduct, it can shut down such establishments (Federal Law of Consumer Protection, 1992). Therefore, this Institution works more as a problem-solving organism, despite its efforts to educate consumers, as eventually, even a well-informed consumer can be a victim of food poisoning or fraud.

\section{LOCAL BUSINESS REGULATION}

Mexican municipalities are responsible for public service delivery and promotion of the organic growth of the cities (Chamber of Deputies, 1917). Therefore, since they must achieve the purposes specified by the Constitution (Chamber of Deputies, 1917), it is normal to observe that all the Municipalities have pretty much the same rules or laws. As regards commercial issues, the City Halls would regulate the area of municipal jurisdiction, commercial and industrial performances, both private and public agro-industrial and services activities, as well as the exploitation of material banks, executed on a regular or occasional basis, with or without accommodation according to their impact on the fundamental aspects of community life, including those relating to public safety, general planning of human settlements, urban development, usage, destination and land use, planning and adequate provision of municipal services and public work, as long as such regulations are not reserved to other authorities (Municipal Gazette, 2014).

Thus, in case a citizen wants to open a new store, he/she must satisfy some prerequisites. The first step that needs to be made is to obtain a municipal license. For instance, in the $\mathrm{Mu}$ nicipality of Zapopan, one should deliver the following documentation in order to get a license for a beauty shop (Portal Zapopan, 2015):

- Append Charter Manager or Market Square.

- Business Opinion(Purchase registration form to register in boxes).

- Copy and original documents of a person whose property is being accredited.

- Current photographs of business premises and / or the property or area. 
- An original and one copy of the holder's identification.

- Original and a copy of the notice of operation to the secretary of health.

Once the municipal license has been obtained, it is required to secure parking spaces (Municipal Gazette, 2014 b) upon which the person might be able to open his/her own beauty shop. The same process is applicable to all municipalities, with slight variations.

\section{SOCIAL NETWORKS AND THEIR USE IN LOCAL COMMERCE}

Over the last few years, Mexican Internet users have developed certain habits. Currently, 20\% of them purchase online, and $16 \%$ of the companies need the Internet so that they can manage social networks for commercial purposes (Menéndez \& Enríquez, 2014).

The use of the Internet is increasing each year (Menéndez \& Enríquez, 2014) and with the national telecommunications reform entering into force on January 1, 2015, an increase in the expansion of the fundamental rights such as the freedom of expression and access to information is expected. The rights of telecommunications and broadcasting service users are going to be extended. The right of access to information and communication technologies, including broadband and the Internet, is going to be recognized. The reform highlights that telecommunications and broadcasting are public services of general interest, resulting from the state guaranteeing that they will be provided under conditions of competition, quality, diversity, universal coverage, networking, convergence, free access and continuity (Municipal Gazette, 2014 b). In this scenario, where $90 \%$ of the Internet users have a social network, a new local commerce shall emerge.

\section{CONCLUSIONS}

Consumers in Mexico are protected by PROFECO (2015.), regardless of the purchasing method (either online or in any other traditional way). Municipalities are in charge of regulating the local commerce, but they do not have necessary tools or rules for developing virtual space commerce like the social networks. Since $90 \%$ of 46 million users have some social network, plenty of those local companies have tried using the same tool for sales and consumer attraction, which further resulted in $20 \%$ of online purchases (Menéndez \& Enríquez, 2014). However, City Halls failed to notice these figures.

The Telecommunications Reform that has been released this year will increase the number of the Internet users, along with the growing number of social network users.

On the other hand, having a local shop outdoors can be very difficult because of the excessive bureaucracy of the Municipalities, thus making it more attractive for merchants and regular citizens to establish commerce through social networks, and avoid all the administrative procedures.

In this century, the Mexican society is changing all of its habits, mostly as a result of the Internet becoming a fundamental part of their lives. Owing to this, the government has been making efforts to improve the right of access to information and communication technologies, which requires further improvement of laws and regulations. This has further triggered the following few proposals:

1. Creating a collaboration agreement with the Federal Government through PROFECO, so that Municipalities can be aware of the business that might be taking place in their own jurisdiction.
2. Easing of bureaucracy, since there are too many requirements prior to obtaining a municipal license.

3. Improving the faculties handled by City Halls, thus making it possible to have a virtual jurisdiction over trades occurring on social networks.

\section{REFERENCES}

Chamber of Deputies. (1917). Mexican Political Constitution, February 5,1917, last actualization in the Official Diary of the Federation in July-07-2014, article 115. Available from: http:// www.diputados.gob.mx/LeyesBiblio/htm/1.htm

Chamber of Deputies. (2015). Expenditure Budget Of The Federation For The Fiscal Year 2015, Chapter One, Federal resources transferred to states, municipalities and the territorial demarcations of the Federal District, p. 3. Available from: http:// www.diputados.gob.mx/LeyesBiblio/pdf/PEF_2015.pdf

Federal Law of Consumer Protection. (1992). New Law published in the Official Journal of the Federation on December 24, 1992, last actualization in the Official Diary of the Federation in April-09-2014, articles 128BIS, 128 TER. Available from: http:// www.profeco.gob.mx/juridico/pdf/l_lfpc_ultimo_camDip.pdf

INEGI. (2014). Estadísticas A Propósito Del Día Mundial De Internet (17 De Mayo). Available from: http://www.inegi.org. $\mathrm{mx} /$ inegi/contenidos/espanol/prensa/contenidos/estadisticas/2014/internet0.pdf

Menéndez, P., \& Enríquez, E. (2014). Estudio sobre los hábitos de Internet en México. Available from: https://www.amipci.org. $\mathrm{mx} /$ estudios/habitos_de_internet/Estudio_Habitos_del_Internauta_Mexicano_2014_V_MD.pdf

Municipal Gazette. (2014 a). Regulation of trade and services for the district of Zapopan Jalisco. Municipal Gazette 19 (41), pp. 1-2. Available from: http://www.zapopan.gob.mx/wp-content/ uploads/pdf/reglamentos_zapopan/ComercioyServicio.pdf

Municipal Gazette. (2014 b). Regulation of buildings and urban development of the town of Zapopan, Jalisco. Municipal Gazette 19 (44), p. 19. Available from: http://www.zapopan.gob.mx/ wp-content/uploads/pdf/reglamentos_zapopan/Construccion.pdf

Official Gazette of the State of Jalisco. (2015). Revenue act of Zapopan, Jalisco for fiscal year 2015 Decree number 25281 / LX / 14. Available from: http://zapopan.s3.amazonaws. com/wp-content/uploads/2011/05/Ley-de-Ingresos-delMunicipio-de-Zapopan-Jalisco-para-el-Ejercicio-Fiscal-dela\%C3\%B1o-2015.pdf

Portal Zapopan. (2015). Register and Licenses. Formalities. Available from: http://portal.zapopan.gob.mx/pyl/licencias/forma. asp

PROFECO. (2015 a). Who are we? Available from: http://www.profeco.gob.mx/english.htm

PROFECO. (2015 b). Monitoreo de tiendas virtuales. Available from: http://www.profeco.gob.mx/ecomercio/Ultimo_Monitoreo.pdf

Valenzuela, J. (2011). El Berlín 1989 de los árabes. Available from: http://www.elpais.com/especial/revueltas-en-el-mundo-arabe/egipto/

Vallarta, P.J.G. (2002). El Municipio en México. In Federalismo y Regionalismo Memoria del VII Congreso Iberoamericano de Derecho Constitucional, pp. 549 - 574. México: Instituto de Investigaciones Jurídicas de la Universidad Nacional Autónoma de México. Available from: http://biblio.juridicas.unam. $\mathrm{mx} / \mathrm{libros} / 1 / 348 / 22 . p d f$ 